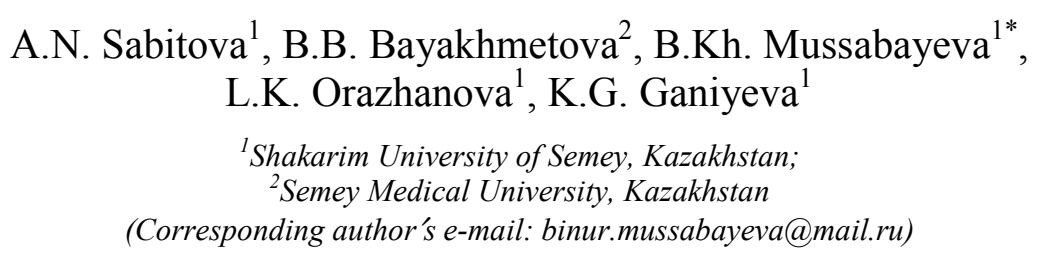

\title{
Sorption of heavy metals by humic acids of chestnut soils
}

\begin{abstract}
The purpose of this article is to study the sorption of heavy metals by humic acids of light and dark chestnut soil. The objects of research are the samples of dark and light chestnut soils, selected from an ecologically clean area of East Kazakhstan. Humic acids (HA) were separated from the soil at different $\mathrm{pH}$ values. At the same time the yield of HA was $0.075 \%$ from dark chestnut soil at $\mathrm{pH} 1.0$, and it was $0.017 \%$ from light chestnut at $\mathrm{pH}=7.0$. Further, the dependence of the sorption degree on the medium acidity was established. It was found that zinc and cadmium are better sorbed in a strongly acidic medium $(\mathrm{pH}<1.0 ; 84.14 \%)$, while lead is preferably sorbed at $\mathrm{pH} 6.0$, and the degree of its sorption is higher $(93.54 \%)$. It was established that metals have a mutual effect, suppressing or enhancing the sorption of each other in bi- and polyelement variants. It was shown that cadmium significantly suppresses lead sorption in neutral media. Zinc more often increases the sorption of both cadmium and lead by 3 times. It was concluded that the binding of heavy metal ions by the organic fraction of the soil occurs due to the complexation with humic acids.
\end{abstract}

Keywords: heavy metals, dark chestnut soils, light chestnut soils (Kastanozems), organic fraction of soil, humic acids, sorption, zinc, lead, cadmium, East Kazakhstan, Borodulikha.

\section{Introduction}

Currently, the biosphere receives a huge amount of various pollutants, including heavy metals (HM), as a result of industrial and anthropogenic human activities. One of the most important parts of the biosphere is the soil cover, since in many cases it acts as a buffer, preventing or localizing contamination of other parts of the biosphere. The entry of HM into the biosphere leads to their accumulation in the soil in quantities that repeatedly exceed the background level, which reduces soil productivity and negatively affects the animal and plant world, as well as ultimately the human body [1-3].

Technogenic contribution in to the urban megalopolis soils is mainly manifested in a sharp increase in the specific concentration of mobile forms of $\mathrm{Zn}, \mathrm{Pb}, \mathrm{Cu}$, and in a lesser extent of $\mathrm{Cd}, \mathrm{V}, \mathrm{Co}, \mathrm{Ni}$ [2-4]. Toxic elements in soils are found in the form of light-exchange ions, colloidal particles, complex compounds, isomorphic impurities, complexes with humic acids, adsorbed complexes on iron and manganese hydroxides, on clay dispersed minerals, and carbonates [5-6].

It is known that soils differ in their sorption capacity in relation to heavy metals [7-11]. At the same time, it is believed that the ability to sorption of heavy metals is associated with the presence of specific high-molecular polyfunctional natural ligands in the organic part of the soil-humic acids (HA), fulvic acids and humin. Soils with a large supply of humic acids can bind a large amount of heavy metals. This is facilitated by the presence of a large number of different functional groups in the HA (carboxylic, alcoholic, phenolic, amine, amide, etc.), which provide the formation of strong complexes of these acids with heavy metal ions [12-14]. The interaction between humic acids and metals can occur by forming ionic, covalent, and chelated compounds [15].

The phenomena of ion exchange, surface sorption, coagulation and peptization play an important role in the sorption of HM by the soil fraction. The ratio of the mass fraction of organic matter to metal is important. HM sorption by the organic part of the soil can occur with the participation of carboxyl $(-\mathrm{COOH})$ and phenolic $(-\mathrm{OH})$ groups, this happens by replacing hydrogen with metal ions. Chelate complexes are formed as a result. The metal binds by chelating coordination (homeopolar) bonds and does not behave like a cation. Metal complex: organic matter can also be formed by replacing metal with a hydrogen cation outside the functional groups [16-17].

\footnotetext{
${ }^{*}$ Corresponding author
} 
Consequently, metals can enter both the cationic and anionic parts of humic acid molecules. It should be noted that the molecules of humus compounds of different soils differ in the number of functional groups and the degree of the «core» condensation. Therefore, sorption is influenced not only by the properties of metals, but also by the structure of humus compounds [18].

Contamination of the soil of East Kazakhstan with heavy metals has been studied by other scientists of Kazakhstan [19-21]. However the sorption degree of heavy metals ( $\mathrm{Zn}, \mathrm{Cd}, \mathrm{Pb}$ ) by the main components of the organo-mineral matrix of dark and light chestnut soil under conditions of mono- and polyelement pollution will be studied for the first time.

Data on the adsorption capacity of soils can serve as a basis for the development of methods for controlling the transformation of forms of chemical element compounds in areas that have been confirmed by technogenic pollution.

This paper presents the results of studying the processes of zinc, lead, and cadmium sorption in monoand polyelement variants by humic acids of dark and light chestnut soil from the East Kazakhstan region.

\section{Experimental}

The objects of research are the samples of dark and light chestnut soils, selected from an ecologically clean area Borodulikha district of East Kazakhstan.

Borodulikha district is located in the North of the East Kazakhstan region. The total area is 7.2 thousand square meters, bordering the Altay region of the Russian Federation, as well as with Shemonaikha, Beskaragay districts and Semey sity. Soils are saline and chestnut in the West of the district, and black earth (Chernozem) in the East of the district.

There is the Zhezkent mining and processing plant on the territory of the district, which is engaged in the extraction of polymetallic ores, and a number of reprocessing enterprises.

The organic part of dark and light brown was isolated according to the standard method [9], by threefold extraction with $0.1 \mathrm{M} \mathrm{NaOH}$ solution. The soil suspension was filled with an extractant solution and shaken on a rotator for one hour. The resulting suspension was filtered, and the remaining soil in the flask was filled with a new portion of $0.1 \mathrm{M}$ alkali solution. The extraction of organic matter was repeated three times.

Humic acids were separated from the filtrate by adding a $10 \%$ solution of sulfuric acid to $\mathrm{pH}=1$. The resulting precipitate was filtered and washed with water, and then dissolved in $0,1 \mathrm{M}$ sodium hydroxide solution. Separate fractions of humic acids were deposited from the resulting solution by addition of $1 \%$ sulfuric acid solution drop by drop to the resulting solution of humic acids to $\mathrm{pH}=7$. The precipitate was separated by centrifugation after 2 hours of settling. A $1 \%$ solution of sulfuric acid was added to the centrifuge again drop by drop to $\mathrm{pH}=7$. All operations for separation of sediment were repeated similarly according to the above method.

Similar operations were performed by depositing fractions at $\mathrm{pH} 5.0 ; 4.0 ; 3.0 ; 2.0 ; 1.0$ and at $\mathrm{pH}<1.0$. The resulting fractions were dried on pre-dried paper filters to a constant weight. The mass of fractions was determined by the difference in the mass of «clean» filters and filters with organic matter after drying.

Thus, 7 organic fractions of dark chestnut soil at $\mathrm{pH}=7.0 ; 6.0 ; 4.0 ; 3.0 ; 2.0 ; 1.0$ and $<1.0,8$ organic fractions of light chestnut soil at $\mathrm{pH}=7.0 ; 6.0 ; 5.0 ; 4.0 ; 3.0 ; 2.0 ; 1.0$ and $<1.0$ were isolated. The organic fraction at $\mathrm{pH}=5.0$ for the dark chestnut soil was not considered due to the negligible allocation of humic acids into a separate fraction.

The study of sorption processes of heavy metals in mono-, bi- and polyelement variants of organomineral matrix of dark chestnut and light chestnut soil was carried out in accordance with [1]. Solutions of $\mathrm{Zn}\left(\mathrm{NO}_{3}\right)_{2}, \mathrm{~Pb}\left(\mathrm{CH}_{3} \mathrm{COO}\right)_{2}$, and $\mathrm{Cd}\left(\mathrm{CH}_{3} \mathrm{COO}\right)_{2}$ salts were used for the model test. The salt concentration was $2.5 \mathrm{mmol} / \mathrm{ml}$ for mono-and bi-element variants and $1.25 \mathrm{mmol} / \mathrm{ml}$ for poly-element variant.

The solution of humic acids isolated at $\mathrm{pH}=7.0$ was divided into 7 equal parts, in which a certain volume of zinc, lead, cadmium salts or their mixtures was added. The following options for applying HM solutions were used:

1. mono-element

2. bi-element

3. poly-element

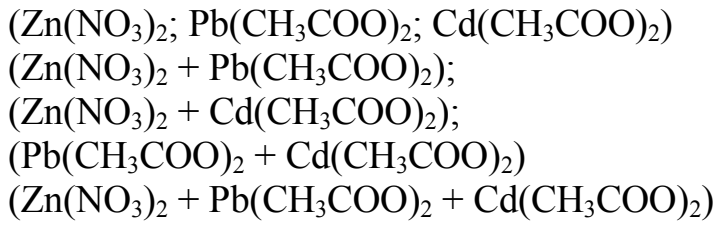


A $10 \%$ solution of sulfuric acid was added to the resulting solutions to $\mathrm{pH}=1.0$. Humic acids were precipitated in all studied solutions. Then the solutions were infused for a day and centrifuged. The content of heavy metals (zinc, lead, cadmium, zinc-lead, zinc-cadmium, lead-cadmium, zinc-lead-cadmium) was determined in the centrifugate. The percentage of sorption was determined by the difference in concentration in the initial standard solution and the extract obtained after the sorption process.

Gross content and concentration of water-soluble, acid exchange forms of zinc, cadmium and lead in the analyzed solution was determined by extraction photometric method with ditizone using a photometer.

\section{Results and Discussion}

7 well-separated fractions have been formed by the triple extracted organic part of dark chestnut soil and 8 well-separated fractions have been formed by the light chestnut soil. Their isoelectric points correspond to the following $\mathrm{pH}$ values of the medium: $7.0 ; 6.0 ; 5.0 ; 4.0 ; 3.0 ; 2.0 ; 1.0$ and $<1.0$.

In all fractions, the content of humic acids and organic fractions from the total content of organic matter was determined by gravimetry (Tables 1,2 ).

Ta b le 1

Content of humic acids and organic substances in the dark chestnut soil

\begin{tabular}{|c|c|c|}
\hline Fractions at $\mathrm{pH}$ & Humic acids content, $\%$ & Organic substances content, $\%$ \\
\hline$<1.0$ & $0.075 \pm 0.001$ & $29.00 \pm 2.15$ \\
\hline 1.0 & $0.050 \pm 0.002$ & $18.50 \pm 1.02$ \\
\hline 2.0 & $0.025 \pm 0.001$ & $9.15 \pm 0.98$ \\
\hline 3.0 & $0.013 \pm 0.001$ & $3.20 \pm 0.24$ \\
\hline 4.0 & $0.020 \pm 0.001$ & $6.24 \pm 0.25$ \\
\hline 5.0 & - & - \\
\hline 6.0 & $0.034 \pm 0.001$ & $11.71 \pm 1.13$ \\
\hline 7.0 & $0.061 \pm 0.002$ & $25.07 \pm 1.89$ \\
\hline
\end{tabular}

As can be seen in Table 1, the content of humic acids and organic substances prevails in fractions with $\mathrm{pH}<1.0(0.075 \%$ and $29.00 \%), 1.0(0.050 \%$ and $18.50 \%)$ and $7.0(0.061 \%$ and $25.07 \%)$, which indicates that these fractions are enriched with organic substances.

$\mathrm{Tab} l \mathrm{e} 2$

Content of humic acids and organic substances in the light chestnut soil

\begin{tabular}{|c|c|c|}
\hline Fractions at $\mathrm{pH}$ & Humic acids content, $\%$ & Organic substances content, $\%$ \\
\hline$<1.0$ & $0.012 \pm 0.001$ & $19.00 \pm 1.67$ \\
\hline 1.0 & $0.013 \pm 0.002$ & $14.25 \pm 1.19$ \\
\hline 2.0 & $0.010 \pm 0.001$ & $13.00 \pm 1.14$ \\
\hline 3.0 & $0.009 \pm 0.002$ & $9.55 \pm 1.05$ \\
\hline 4.0 & $0.009 \pm 0.002$ & $12.20 \pm 1.17$ \\
\hline 5.0 & $0.008 \pm 0.001$ & $10.70 \pm 1.12$ \\
\hline 6.0 & $0.011 \pm 0.001$ & $1.85 \pm 0.12$ \\
\hline 7.0 & $0.017 \pm 0.002$ & $20.25 \pm 1.53$ \\
\hline
\end{tabular}

As can be seen in Table 2, the content of humic acids and organic substances prevails in fractions with $\mathrm{pH}<1.0(0.012 \%$ and $19.00 \%)$, and $7.0(0.017 \%$ and $20.25 \%)$, which indicates that these fractions are enriched with organic substances.

Thus, the highest yield of humic acids and organic substances was obtained at $\mathrm{pH} 1.0 ; \mathrm{pH}<1.0 ; \mathrm{pH} 7.0$ for dark chestnut soil, and at $\mathrm{pH}<1.0 ; \mathrm{pH} 7.0$ for light brown soil.

The isolated fractions of humic acids were studied by IR spectroscopy to determine the identification of functional groups included in the composition.

Figure 1 presents the IR spectrum of humic acids isolated from dark chestnut and light chestnut soils of the Borodulikha region. 


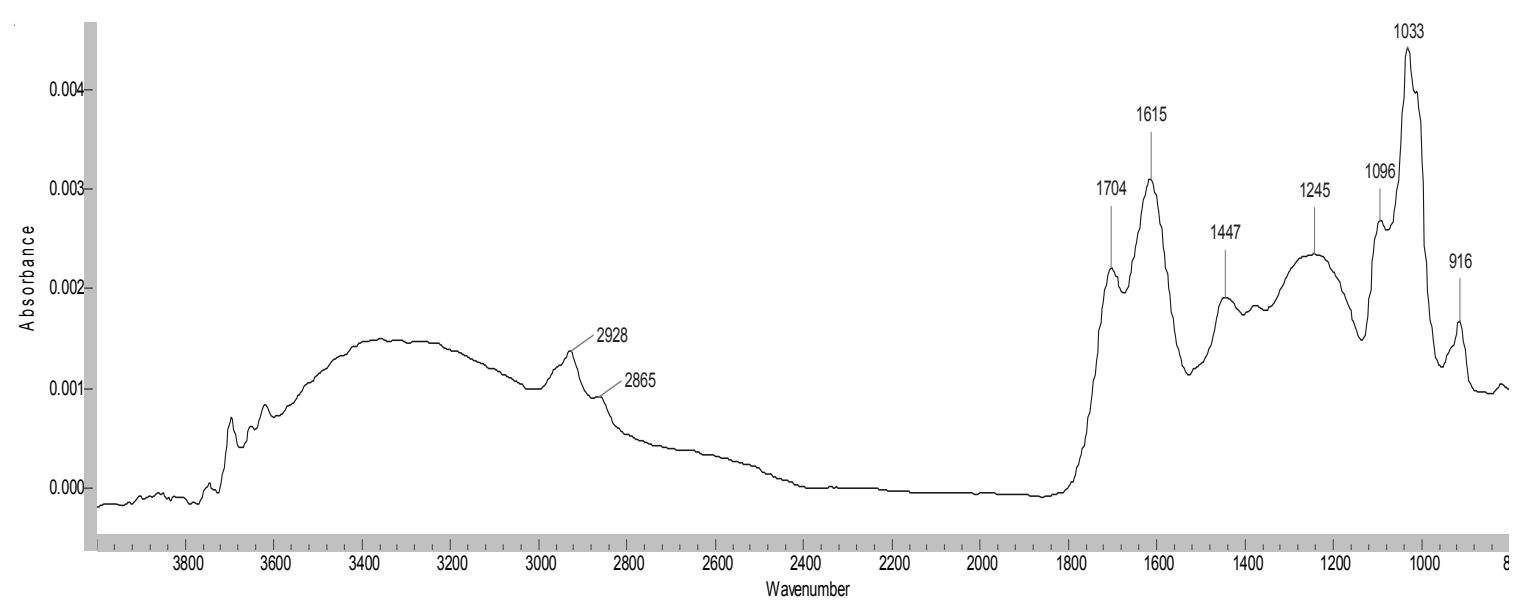

Figure 1. IR spectrum of humic acids

All absorption bands are presented in the IR spectra of the studied humic acids, which is confirmed the presence of the aromatic part (core) and external aliphatic chains in macromolecules. The characteristic absorption bands are in the range of 1000-1800 $\mathrm{cm}^{-1}$. Absorption bands with maxima at $1033 \mathrm{~cm}^{-1}$ are caused by fluctuations in the $\mathrm{O}-\mathrm{H}$ bond of primary alcohol groups. Absorption bands with maxima at 2865 and $2928 \mathrm{~cm}^{-1}$ are caused by valence fluctuations of $-\mathrm{CH}_{3}$ and $-\mathrm{CH}_{2}$ groups of the side chain. The narrow band with a maximum at $1704 \mathrm{~cm}^{-1}$ belongs to the carboxyl group - $\mathrm{COOH}$. Aromatic and aryl-alkyl esters correspond to the absorption band at $1245 \mathrm{~cm}^{-1}$. The absorption peak at $2865 \mathrm{~cm}^{-1}$ indicates the presence of alicyclic compounds. The presence of aromatic rings in humic acid molecules is indicated by the absorption band at $1615 \mathrm{~cm}^{-1}$, which is caused by valence vibrations of the skeletal bonds of the aromatic rings.

The results of zinc, cadmium and lead sorption by organic fractions of dark and light chestnut soil in mono-, bi- and poly-element variants are presented in Tables 3, 4 respectively.

Ta a le 3

Degree of metal sorption by organic fraction of dark chestnut soil in mono-, bi- and poly-element variants

\begin{tabular}{|c|c|c|c|c|c|c|c|c|}
\hline \multirow{2}{*}{\multicolumn{2}{|c|}{ Variant }} & \multicolumn{7}{|c|}{ Degree of sorption, $\%$} \\
\hline & & pH 7.0 & $\mathrm{pH} 6.0$ & pH 4.0 & $\mathrm{pH} 3.0$ & pH 2.0 & $\mathrm{pH} 1.0$ & $\mathrm{pH}<1.0$ \\
\hline \multicolumn{2}{|l|}{$\mathrm{Zn}$} & $52.06 \pm 0.01$ & $55.06 \pm 0.03$ & $56.00 \pm 0.01$ & $76.59 \pm 0.01$ & $72.21 \pm 0.01$ & $74.55 \pm 0.01$ & $4.14 \pm 0.01$ \\
\hline \multicolumn{2}{|l|}{$\mathrm{Pb}$} & $85.71 \pm 0.01$ & $93.54 \pm 0.02$ & $41.91 \pm 0.01$ & $34.57 \pm 0.01$ & $37.38 \pm 0.01$ & $35.58 \pm 0.01$ & $14.14 \pm 0.01$ \\
\hline \multicolumn{2}{|l|}{$\mathrm{Cd}$} & $29.02 \pm 15.03$ & $56.56 \pm 0$ & & & & $15.75 \pm 0$ & \\
\hline \multirow{2}{*}{$\mathrm{Zn} / \mathrm{Pb}$} & $\mathrm{Zn}$ & $76.17 \pm 0.01$ & $77.45 \pm 0.02$ & $78.17 \pm 0.02$ & $54.19 \pm 0.01$ & $42.13 \pm 0.01$ & $19.97 \pm 0,01$ & $68.28 \pm 0.01$ \\
\hline & $\mathrm{Pb}$ & $76.97 \pm 0.02$ & $77.39 \pm 0.02$ & $67.54 \pm 0.03$ & $65.11 \pm 0.01$ & $71.46 \pm 0.01$ & $59.38 \pm 0.01$ & $53.43 \pm 0.01$ \\
\hline \multirow{2}{*}{$\mathrm{Zn} / \mathrm{Cd}$} & $\mathrm{Zn}$ & $76.76 \pm 0.03$ & $77.56 \pm 0.02$ & $63.15 \pm 0.02$ & $66.03 \pm 0.01$ & $45.11 \pm 0.01$ & $21.78 \pm 0.01$ & $63.33 \pm 0.01$ \\
\hline & $\mathrm{Cd}$ & $81.09 \pm 0.06$ & $81.70 \pm 0.06$ & $82.20 \pm 0.12$ & $79.42 \pm 0.01$ & $54.78 \pm 0.02$ & $48.61 \pm 0.01$ & $47.14 \pm 0.02$ \\
\hline \multirow{2}{*}{$\mathrm{Pb} / \mathrm{Cd}$} & $\mathrm{Pb}$ & $13.62 \pm 0.02$ & $11.10 \pm 0.12$ & $49.77 \pm 0.01$ & $47.93 \pm 0.01$ & $73.52 \pm 0.01$ & $75.19 \pm 0.01$ & $54.48 \pm 0.01$ \\
\hline & $\mathrm{Cd}$ & $28.77 \pm 0.07$ & $39.08 \pm 0.04$ & $53.68 \pm 5.77$ & $92.48 \pm 0.01$ & $93.18 \pm 0.01$ & $73.89 \pm 0.01$ & $29.21 \pm 0.01$ \\
\hline \multirow{3}{*}{$\mathrm{Zn} / \mathrm{Pb} / \mathrm{Cd}$} & $\mathrm{Zn}$ & $84.25 \pm 0.02$ & $84.52 \pm 0.01$ & $73.76 \pm 0.01$ & $37.18 \pm 0.02$ & $62.09 \pm 0.01$ & $57.12 \pm 0.01$ & $43.19 \pm 0.01$ \\
\hline & $\mathrm{Pb}$ & $84.49 \pm 5.78$ & $84.35 \pm 0.02$ & $80.80 \pm 0.01$ & $78.63 \pm 0.02$ & $47.88 \pm 0.01$ & $11.41 \pm 0.01$ & $35.82 \pm 0.01$ \\
\hline & $\mathrm{Cd}$ & $90.49 \pm 0.02$ & $90.65 \pm 0.02$ & $90.04 \pm 0.01$ & $88.69 \pm 0.02$ & $47.22 \pm 0.01$ & $73.48 \pm 0.01$ & $57.72 \pm 0.01$ \\
\hline
\end{tabular}

As can be seen in Table 3, the sorption of zinc was almost identical (sorption degree $52.06 \% ; 55.06 \%$ and $56.00 \%$ ) by organic fractions with $\mathrm{pH} 7.0 ; 6.0 ; 4.0$ in mono-element variant. The sorption of zinc was increased with further acidification, for example, it was increased by 1.5 times at $\mathrm{pH}=3.0(76.59 \%)$ compared to the value at $\mathrm{pH}=7.0(52.06 \%)$.

The degree of zinc sorption increased at $\mathrm{pH} 7.0 ; 6.0 ; 4.0$ (76.17\%; $77.45 \% ; 78.17 \%)$ with equivalent enrichment of each fraction with zinc and lead, except for highly acidic environments.

The cadmium presence also increased the zinc absorption, for example, the sorption degree was increased by 1.5 times at typical for this soil reaction medium $\mathrm{pH}$ 7.0-6.0 in comparison with the monoelement experiment. The same results were obtained with the combined presence of lead and cadmium. 
The character of lead sorption in various versions of the experiment is similar to that in fractions with isoelectric points at $\mathrm{pH} 7.0 ; 6.0 ; 3.0$ and is radically different from fractions with $\mathrm{pH} 2.0 ; 1.0 ;<1.0$. The sorption patterns shown at $\mathrm{pH} 4$ are intermediate.

The greatest absorption of lead was observed in $\mathrm{pH} 7.0 ; 6.0$ fractions; the degree of sorption was decreased with acidification of the medium, for example, it decreased by 2 times at $\mathrm{pH} 4.0 ; 1.0$ compared to $\mathrm{pH}$ 6.0. In the presence of an equivalent amount of zinc, lead sorption was slightly suppressed in fractions with $\mathrm{pH} 7.0 ; 6.0 ; 3.0 ; 2.0$, and Vice versa, it was enhanced by the $\mathrm{pH} 4.0$ and 1.0 medium reaction. Cadmium was even more deactivated processes of lead enrichment:

- by 6.3 times compared to the monoelement experiment in the fraction with $\mathrm{pH} 7.0$;

- by 8.4 times at $\mathrm{pH} 6.0$.

The absorption of lead was not affected by the presence of cadmium in fractions with $\mathrm{pH} 4.0$ and 2.0. The combined presence of zinc and cadmium did not lead to any changes in the lead sorption as compared with mono-element variant reaction by organic fraction of dark chestnut soil ( $\mathrm{pH} \mathrm{6-7).} \mathrm{Consequently,} \mathrm{both}$ zinc and cadmium reduce the degree of sorption, but the influence of zinc is more predominant in their combined presence.

Fractions at $\mathrm{pH} 7.0 ; 6.0 ; 4.0$, as well as at $\mathrm{pH} 3.0$ and 2.0 , showed general regularities in the cadmium sorption in different versions of the experiment. The absorption dynamics is not unequal when the acidity increases.

The presence of zinc has a «catalyzing» effect on the cadmium sorption (approximately 3 times compared to the values of the monoelement variant in fractions with $\mathrm{pH} \mathrm{7.0;6.0;4.0} \mathrm{and} \mathrm{1.0).} \mathrm{The} \mathrm{presence} \mathrm{of}$ lead does not have significant changes at $\mathrm{pH} 7.0 ; 6.0$ and slightly increases sorption in more acidic fractions. In poly-element absorption variant, the sorption of cadmium is influenced more by the presence of lead, since sorption is comparable to those regularities that were deduced in the bi-element experiment in the pres-

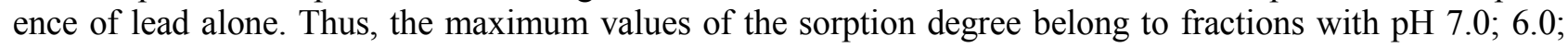
4.0 in poly-element absorption variant. The degree of absorption increases almost 3 times compared to the mono-element experiment in these fractions.

Table 4

Degree of metal sorption by organic fraction of light chestnut soil in mono-, bi- and poly-element variants

\begin{tabular}{|c|c|c|c|c|c|c|c|c|c|}
\hline \multirow{2}{*}{\multicolumn{2}{|c|}{ Variant }} & \multicolumn{8}{|c|}{ Degree of sorption, $\%$} \\
\hline & & $\mathrm{pH} 7.0$ & $\mathrm{pH} 6.0$ & pH 5.0 & $\mathrm{pH} 4.0$ & $\mathrm{pH} 3.0$ & $\mathrm{pH} 2.0$ & pH 1.0 & $\mathrm{pH}<1.0$ \\
\hline \multicolumn{2}{|l|}{$\mathrm{Zn}$} & $23.70 \pm 0.01$ & $39.62 \pm 0.01$ & $32.08 \pm 0.02$ & $33.12 \pm 0.01$ & $55.03 \pm 0.01$ & $56.11 \pm 0.01$ & $53.25 \pm 0.02$ & $84.10 \pm 0.02$ \\
\hline \multicolumn{2}{|l|}{$\mathrm{Pb}$} & $82.17 \pm 0.01$ & $88.21 \pm 0.01$ & $27.04 \pm 0.01$ & $25.01 \pm 0.02$ & $13.13 \pm 0.01$ & $18.64 \pm 0.2$ & $23.11 \pm 0.01$ & $25.70 \pm 0.01$ \\
\hline \multicolumn{2}{|l|}{$\mathrm{Cd}$} & $56.23 \pm 0.01$ & $40.24 \pm 0.02$ & $22.61 \pm 0.01$ & $14.51 \pm 0.01$ & $13.42 \pm 0.01$ & $17.93 \pm 0.01$ & $78.04 \pm 0.01$ & $83.65 \pm 0.02$ \\
\hline \multirow{2}{*}{$\mathrm{Zn} / \mathrm{Pb}$} & $\mathrm{Zn}$ & $64.81 \pm 0.01$ & $72.40 \pm 0.01$ & $10.03 \pm 0.03$ & $16.95 \pm 0.01$ & $11.46 \pm 0.02$ & $37.91 \pm 0.01$ & $79.21 \pm 0.01$ & $86.32 \pm 0.01$ \\
\hline & $\mathrm{Pb}$ & $11.30 \pm 0.01$ & $56.72 \pm 1.71$ & $65.02 \pm 0.01$ & $60.41 \pm 0.01$ & $54.36 \pm 0.02$ & $51.71 \pm 0.01$ & $10.95 \pm 0.01$ & $13.47 \pm 0.01$ \\
\hline \multirow{2}{*}{$\mathrm{Zn} / \mathrm{Cd}$} & $\mathrm{Zn}$ & $72.13 \pm 0.02$ & $70.81 \pm 0.01$ & $16.94 \pm 0.01$ & $6.43 \pm 0.01$ & $5.73 \pm 0.01$ & $9.34 \pm 0.02$ & $18.81 \pm 0.01$ & $18.74 \pm 0.01$ \\
\hline & $\mathrm{Cd}$ & $63.00 \pm 0.02$ & $57.11 \pm 0.01$ & $51.82 \pm 0.01$ & $62.22 \pm 0.01$ & $54.93 \pm 0.01$ & $58.81 \pm 0.01$ & $51.74 \pm 0.01$ & $86.20 \pm 0.01$ \\
\hline \multirow{2}{*}{$\mathrm{Pb} / \mathrm{Cd}$} & $\mathrm{Pb}$ & $55.64 \pm 0.02$ & $54.21 \pm 0.02$ & $66.00 \pm 0.02$ & $53.36 \pm 0.01$ & $53.04 \pm 0.02$ & $56.81 \pm 0.01$ & $36.07 \pm 0.01$ & $26.40 \pm 0.02$ \\
\hline & $\mathrm{Cd}$ & $32.11 \pm 0.02$ & $73.73 \pm 0.01$ & $43.60 \pm 0.01$ & $53.23 \pm 0.01$ & $59.27 \pm 0.02$ & $36.00 \pm 0.02$ & $12.40 \pm 0.01$ & $16.83 \pm 0.02$ \\
\hline \multirow{3}{*}{$\mathrm{Zn} / \mathrm{Pb} / \mathrm{Cd}$} & $\mathrm{Zn}$ & $79.93 \pm 0.01$ & $73.55 \pm 0.01$ & $34.21 \pm 0.01$ & $36.42 \pm 0.01$ & $19.42 \pm 0.02$ & $23.83 \pm 0.02$ & $49.86 \pm 0.01$ & $46.13 \pm 0.01$ \\
\hline & $\mathrm{Pb}$ & $67.84 \pm 5.77$ & $53.94 \pm 0.02$ & $70.12 \pm 0.01$ & $73.90 \pm 0.01$ & $67.90 \pm 0.02$ & $72.82 \pm 0.01$ & $69.63 \pm 0.01$ & $47.72 \pm 0.01$ \\
\hline & $\mathrm{Cd}$ & $83.00 \pm 0.02$ & $69.21 \pm 0.01$ & $82.84 \pm 0.02$ & $76.52 \pm 0.01$ & $75.04 \pm 0.01$ & $68.43 \pm 0.01$ & $59.62 \pm 0.01$ & $12.47 \pm 0.01$ \\
\hline
\end{tabular}

The sorption of zinc by the organic fraction of light chestnut soil was slightly different from dark chestnut soil. Dynamics of pollutant absorption within all factions in mono-variant naturally increased. By the nature of zinc sorption in the presence of lead or cadmium and in the simultaneous presence of lead and cadmium, the fractions can be combined into several microgroups: 1) with $\mathrm{pH} 7-6 ; 2$ ) with $\mathrm{pH} 5 ; 4 ; 3 ; 2$; 3 ) with $\mathrm{pH} 1 ;<1$. The first group of fractions is active in normal natural conditions, it is increased its sorption in both in bi- and poly-element variants of the experiment. Moreover, the action of lead and cadmium is almost the same.

Lead and cadmium inhibited the sorption of zinc in the second group of humic acids in light chestnut soil. The cadmium had more competitive action there. For example, at $\mathrm{pH} 2$ the sorption of zinc was suppressed by 1.5 times in the presence of lead and it was suppressed by 6 times in the presence of cadmium in 
comparison with mono-element variant. Zinc absorption was increased in the presence of lead, and it was suppressed it in the presence of cadmium in the group represented by fractions with $\mathrm{pH} 1$ and $<1$.

Lead absorption was suppressed with acidification of fractions in the mono-element version of the experiment. Thus, at $\mathrm{pH} 5$, sorption decreased by about 3 times when compared with the fraction with an isoelectric point at $\mathrm{pH} 7.0$.

Data obtained during bi-element and poly-element experiments indicates that, the lead sorption have been suppressed at $\mathrm{pH} 7.0 ; 6.0$ and have been increased at $\mathrm{pH}$ from 5 to $<1$ by both zinc and cadmium, and their combined presence. The same dynamics of cadmium sorption have been shown by fractions with $\mathrm{pH}$ $6.0 ; 5.0 ; 4.0 ; 3.0 ; 2.0$ relative to the presence of both zinc and lead.

Zinc have been demonstrated a greater activating effect. For example, at $\mathrm{pH} 5.0$ the presence of zinc increased the cadmium absorption by 2.3 times compared to the mono-element experiment, and by 1.9 times in the presence of lead alone. The character of cadmium sorption in poly-element enrichment was more influenced by the presence of zinc in all fractions except $\mathrm{pH}<1$.

In general, the cadmium sorption was suppressed when acidified to $\mathrm{pH} 2.0$ (by 3.1 times compared to $\mathrm{pH}$ 7.0) in mono-element version; it did not change significantly in poly-element enrichment. Almost all fractions increased the cadmium sorption at 2.7 times level compared to the average value of the monoelement experience of these fractions.

It was shown by the comparison of zinc, lead, and cadmium sorption degree values in a mono-element experiment (Fig. 2), that fraction with $\mathrm{pH}$ of 7.0, and 6.0 are indicators for lead (its sorption is more than 1.6 times the sorption of zinc and 3 times more the sorption of cadmium), more acidic fractions are indicators for cadmium (for example, the cadmium sorption is 1.3 times higher sorption of lead and 5.9 times higher sorption of zinc in fraction with $\mathrm{pH} 3.0$ ).

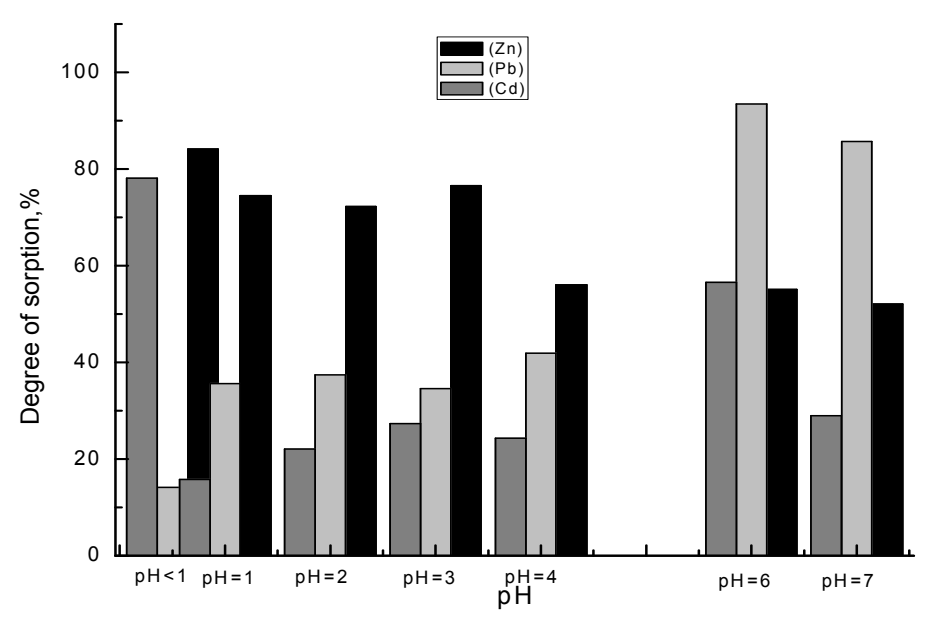

a) specific sorption (multi-element variant)

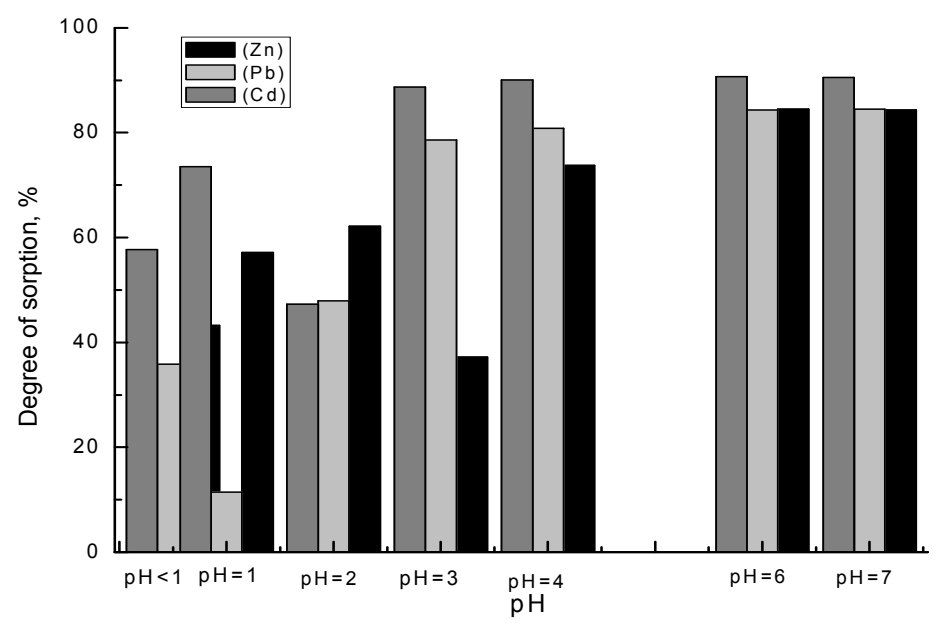

b) competitive sorption (poly-element variant)

Figure 2. Comparison diagram of heavy metals sorption by the organic matrix of dark chestnut soil 
Fractions with the same structure showed similar absorption patterns in the experiment. All the selected fractions can be divided into two groups: 1) $\mathrm{pH} 7.0 ; 4.0 ; 3.0$ and 2) $\mathrm{pH}$ 1.0. Although the structure of the pH 6.0 fraction differs in spectrum from all others, it is characterized by similarity of the sorption character with the first group of fractions mentioned above. Humic acids with $\mathrm{pH} 1.0$ active medium are in this series separately: the individual spectrum also characterizes the distinctive features in the sorbed capacity. It was shown by the comparison of all three metals sorption values (Fig. 3), that the fraction with a neutral medium showed greater affinity to lead, and the acidificated medium showed greater affinity to zinc in the monoelement version.

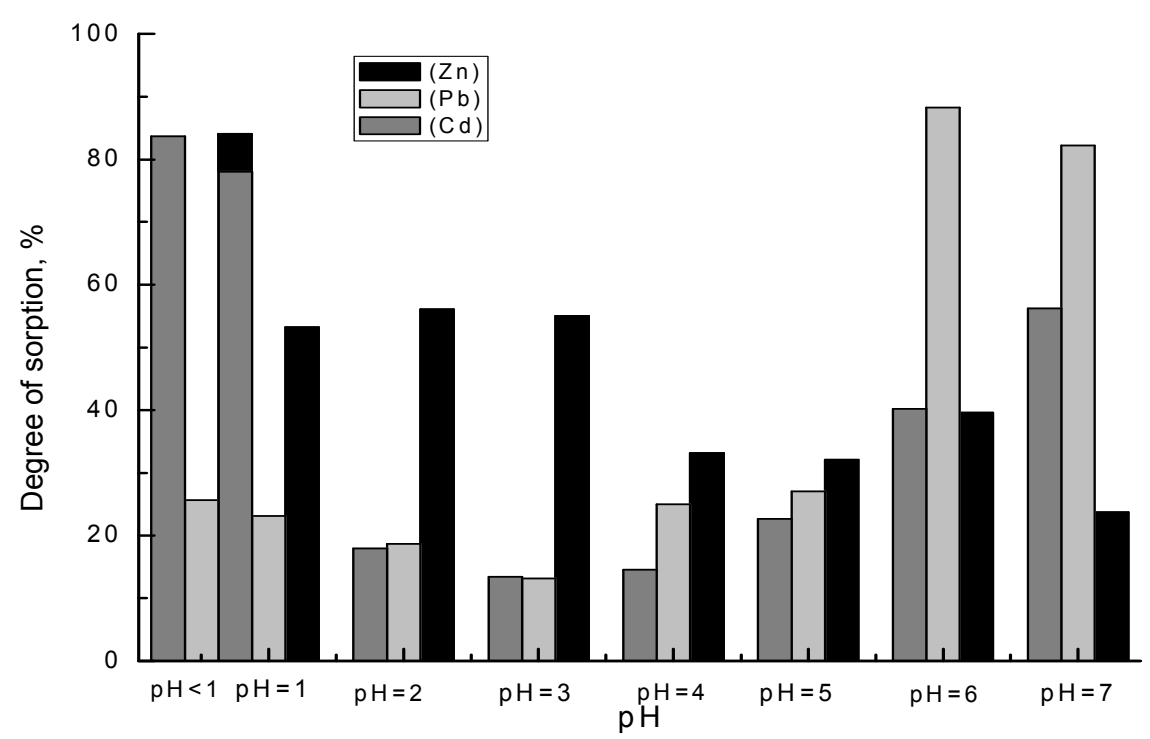

a) specific sorption (multi-element variant)

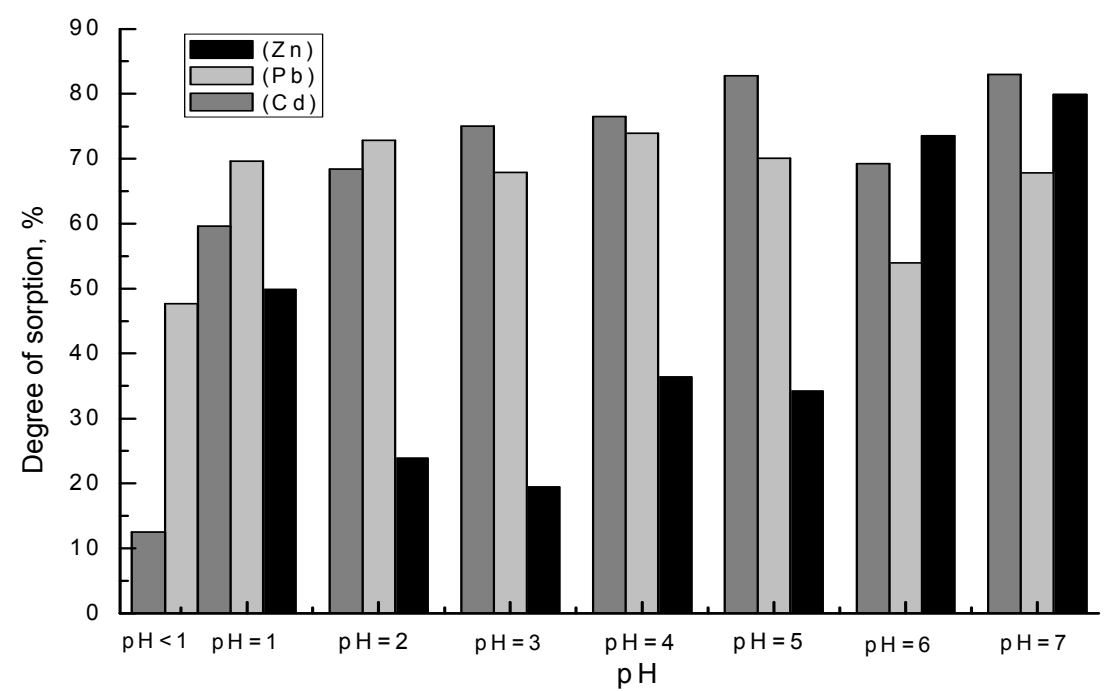

b) competitive sorption (poly-element variant)

Figure 3. Comparison diagram of heavy metals sorption by the organic matrix of light chestnut soil

As can be seen in Figure 3, the percentage of sorption was highest for zinc and cadmium at $\mathrm{pH}<1.0$. The sorption processes were enhanced for all metals, and lead had a competitive effect on zinc and cadmium with the combined presence of all three ions. Similar dynamics of pollutants absorption were shown by fractions with $\mathrm{pH} 6.0 ; 5.0 ; 4.0 ; 3.0$, which have approximately the same character of spectral curves.

The two studied soils showed different sorption activity. The fractions at $\mathrm{pH}=7.0$ (the active fraction for these soils) and at $\mathrm{pH}=6$ of the two soils absorbed the introduced pollutants differently (Figs. 4-6): dark chestnut soil absorbed more zinc than light chestnut soil under equivalent conditions. This can be explained by the low content of organic matter, and, accordingly, by the small percentage (\%) of fractions in light chestnut soil (Tables 3, 4). 


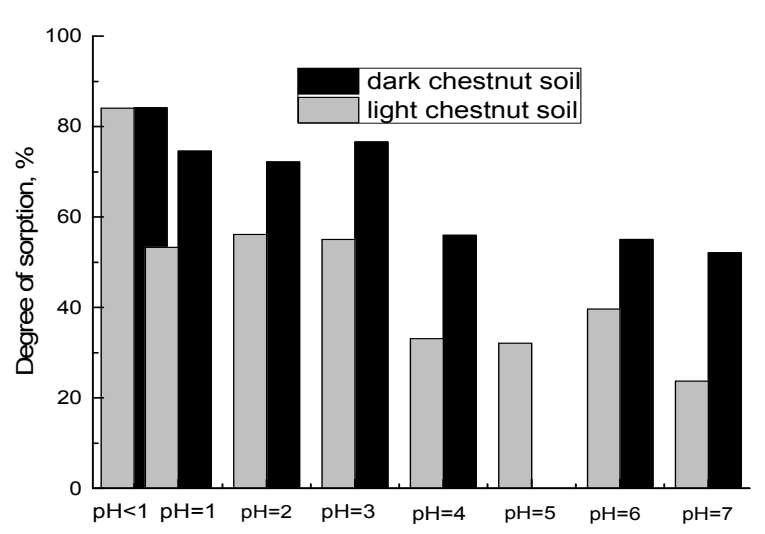

Figure 4. Comparative diagram of zinc sorption in the mono-element experiment

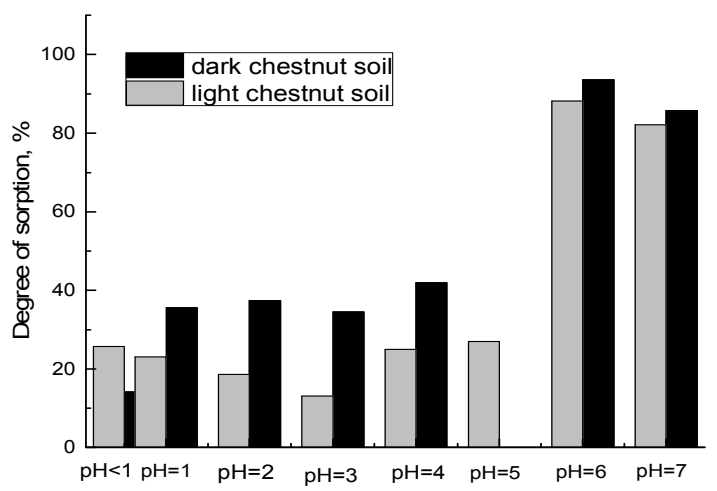

Figure 5. Comparative diagram of lead sorption in a single experience

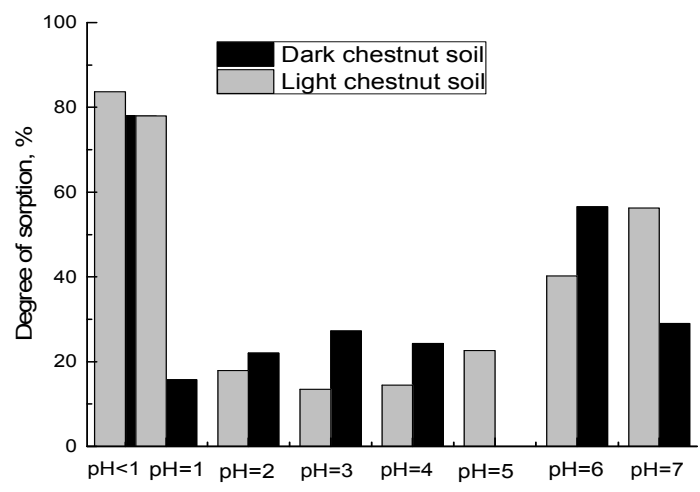

Figure 6. Comparative diagram of cadmium sorption in the mono-element experiment

Thus, since chestnut soils have a slightly alkaline reaction $(\mathrm{pH} 7.2-7.5)$ under normal conditions, all three metals have a high affinity for the organic fraction in poly-element contamination conditions. The sorption intensity is suppressed by acidification.

\section{Conclusions}

Thus, it was shown by the IR spectroscopy data, that extracted from the dark brown and light brown soils of the Borodulikha region humic acids contain primary and secondary alcohols, aromatic hydrocarbons, carboxylic acids, aromatic and aryl-alkyl esters. The presence of such functional groups as $-\mathrm{COOH},-\mathrm{OH}$ in humic acids makes it possible to bind heavy metals to the organic fraction of the soil by forming chelate complexes.

The sorption of heavy metals by the organo-mineral matrix of dark chestnut and light chestnut soil of the ecologically clean Borodulikha region of East Kazakhstan was studied. Soil samples were selected in the Western part of Borodulikha district, where are no industrial enterprises. However, there is deforestation as a 
result of forest fires. Today about $15 \%$ of the district's territory is occupied by pine forest, whereas previously the area of the forest was $50 \%$. Therefore, the study of the degree of soil contamination is relevant.

It was established that the process of zinc, cadmium and lead sorption by organic fractions of dark chestnut and light chestnut soil proceeds differently in mono- and poly-element variants. For mono-element enrichment of the soil, lead is more sorbed by humic acid fractions of the studied soils at $\mathrm{pH} 7.0$ and 6.0, its sorption degree reaches $93.54 \%$; zinc is more sorbed at acidic $\mathrm{pH}$ from 3.0 to $<1$ uncharacteristic for these soils; cadmium is more sorbed by $\mathrm{pH} 1.0$ and $<1$ fractions, their sorption degree at $\mathrm{pH} 1.0$ is $84.14 \%$. Sorption of zinc, lead, and cadmium by humic and hymetomelanic acids of organic matter of chestnut soils under conditions of poly-element enrichment is accompanied by the oppression of one heavy metal by another.

Data obtained on the sorption of heavy metals by soils can be used in assessing the impact of anthropogenic emissions on the environment, in developing practical recommendations to reduce the toxic effect of heavy metals. The results of the work can also be practically applied in rationing systems.

\section{References}

1 Водяницкий Ю.Н. Загрязнение почв тяжелыми металлами / Ю.Н. Водяницкий, Д.В. Савичев, А.Т. Ладонин. - М.: Изд-во Почвенного ин-та им. В.В. Докучаева РАСХН, 2012. - 306 с.

2 Clarke L.W. Urban legacies and soil management affect the concentration and speciation of trace metals in Los Angeles community garden soils / L.W. Clarke, G.D. Jenerette, D.J. Bain // Environmental Pollution. — 2015. — Vol. 197. — P. 1-12.

3 Sharma R.K. Cadmium minimization in food crops by cadmium resistant plant growth promoting rhizobacteria / R.K. Sharma, G. Archana // Applied Soil Ecology. — 2016. — Vol. 107. — P. 66-78.

4 Piri M. Citric acid decreased and humic acid increased Zn sorption in soils / M. Piri, E. Sepehr, Z. Rengel // Geoderma. 2019. - Vol. 341. - P. 39-45.

5 Ding H. Characteristics and interactions of heavy metals with humic acid in gold mining area soil at a upstream of a metropolitan drinking water sourse / H. Ding, L. Tang, Y. Nie, H. Ji // Journal of Geochemical Exploration. — 2019. — Vol. 200. — P. 266-275.

6 Фархутдинов Р.М. Связывание свинца, кадмия и меди гуминовыми кислотами озерных донных отложений / Р.М. Фархутдинов, А.А. Каюгин, Л.В. Черкашина // Вестн. Тюмен. гос. ун-та. — 2010. — № 7. — С. $196-202$.

7 Малышенко Н.В. Сорбция катионов цинка модифицированными гуминовыми кислотами / Н.В. Малышенко, С.И. Жеребцов, О.В. Смотрина, Л.В. Брюховецкая, 3.Р. Исмагилов // Химия в интересах устойчивого развития. — 2015. № 23. - C. 451-457.

8 Boguta P. Insight into the interaction mechanism of iron ions with soil humic acids. The effect of the $\mathrm{pH}$ and chemical properties of humic acids / P. Boguta, V. D'Orazio, N. Senesi, Z. Sokołowska, K. Szewczuk-Karpisz // Journal of Environmental Management. — 2019. - Vol. 245. — P. 367-374.

9 Федоров И.Г. Поведение металлов в присутствии гуминовых веществ в содовых озерах Восточного Забайкалья / И.Г. Федоров, С.В. Борзенко // Вестн. Зайбайкал. гос. ун-та. - 2018. — Т. 2, № 2. - С. 74-80.

10 Wei L. Adsorption behaviors of $\mathrm{Cu}^{2+}, \mathrm{Zn}^{2+}$ and $\mathrm{Cd}^{2+}$ onto proteins, humic acid, and polysaccharides extracted from sludge EPS: Sorption properties and mechanisms / L. Wei, J. Li, M. Xue, Sh. Wang, Q. Zhao // Bioresource Technology. — 2019. Vol. 291. - P. 121868.

11 Calace N. Adsorbtion isotherms and breakthrough curves to study how humic acids influence heavy metal-soil interactions / N. Calace, D. Deriu, B.M. Petronio // Water Air Soil Pollution. — 2009. — Vol. 204, Iss. 2. — P. 373-380.

12 Boguta P. Study of the Interactions between Zn (II) ions and humic acids / P. Boguta, Z. Sokołowska // Plosone. — 2016. Vol. 14, No. 4. - P. 1-20.

13 Zherebtsov S.I. Sorption of copper cations from aqueous solutions by brown coals and humic acids / S.I. Zherebtsov, N.V. Malyshenko, L.V. Bryukhovetskaya, Z.R. Ismagilov, S.Y. Lyrshchikov // Solid Fuel Chemistry. — 2015. — Vol. 49, No. 5. — P. 294-303.

14 Карпюк Л.А. Алкоксисилильные производные гуминовых веществ: синтез, строение и сорбционные свойства: дис. ... канд. хим. наук: 02.00.03 — «Органическая химия» / Леонид Александрович Карпюк. — М., 2008. — 187 с.

15 Заварзина А.Г. Взаимодействие гуминовых кислот различного происхождения с ионами металлов и минеральными компонентами почв: дис. ... канд. биол. наук: 04.00.03 — «Биогеохимия» / Анна Георгиевна Заварзина. — М., 2000. — 134 с.

16 Будаева А.Д. Сорбция ионов тяжелых металлов гуматами аммония, натрия и калия / А.Д. Будаева, Е.В. Золтоев, Н.В. Бодоев, Т.А. Бальбурова // Фундаментальные исследования. — 2005. - № 9. - С. 112, 113.

17 Добровольский Г.В. Структурно-функциональная роль почв и почвенной биоты в биосфере / Г.В. Добровольский, И.П. Бабьева. - М.: Наука, 2003. — 364 с.

18 Алексеев Ю.В. Тяжелые металлы в почвах и растениях / Ю.В. Алексеев. - Л.: Агропромиздат, 1987. — 142 с.

19 Есенжолова А.Ж. Биоиндикационная способность листьев древесных и кустарниковых насаждений для оценки загрязнения среды тяжелыми металлами в зоне действия металлургического комплекса / А.Ж. Есенжолова, М.С. Панин // Экология и промышленность России. — 2013. - № 7. - С. 49-53.

20 Сибиркина А.Р. Биогеохимические особенности накопления соединений тяжелых металлов различными сообществами сосновых боров Семипалатинского Прииртышья / А.Р. Сибиркина // Современные проблемы науки и образования. 2014. — № 3. URL: http://www.scienceeducation.ru/117-13005 
21 Королев А.Н. Тяжелые металлы в почвах и овощных культурах в зоне влияния цементного завода города Семей / А.Н. Королев, В.А. Боев // Вестн. Омск. гос. аграр. ун-та. - 2017. - № 1. - С. 27-33.

\author{
А.Н. Сабитова, Б.Б. Баяхметова, Б.Х. Мұсабаева, Л.К. Оразжанова, К.Г. Ганиева \\ Күрең топырақтың гумин қышқылдарының ауыр металдарды сорбциялауы
}

\begin{abstract}
Мақаланың мақсаты ашық және қою-күрең топырағының гумин қышқылдарымен ауыр металдардың сорбциясын зерттеу. Зерттеу объектілері Шығыс Қазақстанның экологиялық таза ауданынан алынған қою және ашық-күрең топырақ үлгілері болып табылады. Гумин қышқылдары (ГҚ) топырақтан әр түрлі рН мәндерінде бөлініп алынды, бұл ретте ГҚ қою-күрең топырақтан ГҚ шығымы рН 1.0 кезінде $0.075 \%$; pH=7.0 кезінде ашық-күрең топырақтан 0.017 \% құрады. Бұдан әрі сорбция деңгейінің орта қышқылдығына тәуелділігі анықталды. Мырыш пен кадмий күшті қышқыл ортада сорбцияланатыны анықталды (рН 1.0-84.14 \%), ал қорғасын рН 6.0 - 93.54 \% кезінде жақсы сорбцияланады және оның сорбция дәрежесі жоғары. Би- және полиэлементті нұсқаларда металдар бір-бірінің сорбциясын басу немесе күшейту арқылы өзара әсер ететіні анықталды. Кадмий нейтрал ортада қорғасынның сорбциясын едәуір басатыны көрсетілген. Мырыш кадмий мен қорғасын сорбциясын 3 есе арттырады. Ауыр металдар иондарының топырақтың органикалық фракциясымен байланысуы гумин қышқылдарымен комплекс түзілу есебінен болады деген қорытынды жасалды.
\end{abstract}

Кілm сөздер: ауыр металдар, қою-күрең топырақ, ашық-күрең топырақ, топырақтың органикалық фракциясы, гумин қышқылдары, сорбция, мырыш, қорғасын, кадмий, Шығыс Қазақстан, Бородулиха.

\title{
А.Н. Сабитова, Б.Б. Баяхметова, Б.Х. Мусабаева, Л.К. Оразжанова, К.Г. Ганиева
}

\section{Сорбция тяжелых металлов гуминовыми кислотами каштановых почв}

\begin{abstract}
Целью данной статьи является изучение сорбции тяжелых металлов гуминовыми кислотами (ГК) светло- и темно-каштановых почв. Объектами исследования являются образцы темно- и светлокаштановых почв, отобранные из экологически чистого района Восточного Казахстана. Гуминовые кислоты выделены из почвы при различных значениях $\mathrm{pH}$, при этом выход ГК из темно-каштановой почвы при $\mathrm{pH}<1,0$ составил $0,075 \%$, из светло-каштановой при $\mathrm{pH}=7,0-0,017 \%$. Далее была установлена зависимость степени сорбции от кислотности среды. Выявлено, что цинк и кадмий сильнее сорбируются в сильно-кислой среде ( $\mathrm{pH}<1,0 ; 84,14$ \%), тогда как свинец лучше сорбируется при $\mathrm{pH}$ 6,0 , причем степень его сорбции выше $(93,54 \%$ ). В би- и полиэлементных вариантах выявлено, что металлы оказывают взаимное влияние, подавляя или усиливая сорбцию друг друга. Показано, что кадмий значительно подавляет сорбцию свинца в нейтральных средах. Цинк чаще усиливает сорбцию и кадмия и свинца в 3 раза. Сделано заключение, что связывание ионов тяжелых металлов органической фракцией почвы происходит за счет комплексообразования с гуминовыми кислотами.
\end{abstract}

Ключевые слова: тяжелые металлы, темно-каштановая почва, светло-каштановая почва, органическая фракция почвы, гуминовые кислоты, сорбция, цинк, свинец, кадмий, Восточный Казахстан, Бородулиха.

\section{References}

1 Vodyanitsky, Yu. N., Ladonin, D. V., \& Savichev, A. T. (2012). Zahriaznenie pochv tiazhelymi metallami [Contamination of soil with heavy metals]. Moscow: Publ. house of the V.V. Dokuchaev Soil Institute [in Russian].

2 Clarke, L.W., Jenerette, G.D., \& Bain, D.J. (2015). Urban legacies and soil management affect the concentration and speciation of trace metals in Los Angeles community garden soils. Environmental Pollution, 197, 1-12.

3 Sharma, R.K., \& Archana, G. (2016). Cadmium minimization in food crops by cadmium resistant plant growth promoting rhizobacteria. Applied Soil Ecology, 107, 66-78.

4 Piri, M., Sepehr, E., \& Rengel, Z. (2019). Citric acid decreased and humic acid increased Zn sorption in soils. Geoderma, $341,39-45$.

5 Ding, H., Tang, L., Nie, Y., \& Ji, H. (2019). Characteristics and interactions of heavy metals with humic acid in gold mining area soil at a upstream of a metropolitan drinking water sourse. Journal of Geochemical Exploration, 200, 266-275.

6 Farhutdinov, R.M., Kayugin, A.A., \& Cherkashina, L.V. (2010). Sviazyvanie svintsa, kadmiia i medi huminovymi kislotami ozernykh donnykh otlozhenii [Binding of lead, cadmium and copper by humic acids of lake bottom sediments]. Vestnik Tiumenskoho hosudarstvennoho universiteta - Bulletin of Tyumen State University, 7, 196-202 [in Russian]. 
7 Malyshenko, N.V., Zherebtsov, S.I., Smotrina, O.V., Bryukhovetskaya, L.V., \& Ismagilov, Z.R. (2015). Sorbtsiia kationov tsinka modifitsirovannymi huminovymi kislotami [Sorption of zinc cations by modified humic acids]. Khimiia $v$ interesakh ustoichivoho razvitiia - Chemistry for sustainable development, 23, 451-457 [in Russian].

8 Boguta, P., D'Orazio, V., Senesi, N., Sokołowska, Z., \& Szewczuk-Karpisz, K. (2019). Insight into the interaction mechanism of iron ions with soil humic acids. The effect of the $\mathrm{pH}$ and chemical properties of humic acids. Journal of Environmental Management, 245, 367-374.

9 Fedorov, I.G., \& Borzenko, S.V. (2018). Povedenie metallov v prisutstvii huminovykh veshchestv v sodovykh ozerakh Vostochnoho Zabaikalia [Behaviour of metals in the presence of humic substances in soda lakes of East Transbaikalia]. Vestnik Zabaikalskoho hosudarstvennoho universiteta - Bulletin of Zabaykalsk State University, 2(2), 74-80 [in Russian].

10 Wei, L., Li, J., Xue, M., Wang, Sh., \& Zhao, Q. (2019). Adsorption behaviors of $\mathrm{Cu}^{2+}, \mathrm{Zn}^{2+}$ and $\mathrm{Cd}^{2+}$ onto proteins, humic acid, and polysaccharides extracted from sludge EPS: Sorption properties and mechanisms. Bioresource Technology, $291,121868$.

11 Calace, N., Deriu, D., \& Petronio, B.M. (2009). Adsorbtion isotherms and breakthrough curves to study how humic acids influence heavy metal-soil interactions. Water Air Soil Pollution, 204(2), 373-380.

12 Boguta, P., \& Sokołowska, Z. (2016). Study of the Interactions between Zn (II) ions and humic acids. Plosone, 14(4), 1-20.

13 Zherebtsov, S.I., Malyshenko, N.V., Bryuhovetsaya, L.V., \& Lyrshchikov, S.Y. (2015). Sorption of copper cations from aqueous solutions by brown coals and humic acids. Solid Fuel Chemistry, 49(5), 294-303.

14 Karpyuk, L.A. (2008). Alkoksisililnye proizvodnye huminovykh veshchestv: sintez, stroenie i sorbtsionnye svoistva [Alkoxysilyl derivatives of humic substances: synthesis, structure and sorption properties]. Candidate's thesis. Moscow [in Russian].

15 Zavarzina, A.G. (2000). Vzaimodeistvie huminovykh kislot razlichnoho proiskhozhdeniia s ionami metallov i mineralnymi komponentami pochv [Interaction of humic acids of various origin with metal ions and mineral components of soils]. Candidate's thesis. Moscow [in Russian].

16 Budaeva, A.D., Zoltoev, E.V., Bodoev, N.V., \& Balburova, T.A. (2005). Sorbtsiia ionov tiazhelykh metallov humatami ammoniia, natriia i kaliia [Sorption of heavy metal ions by ammonium, sodium and potassium humates]. Fundamentalnye issledovaniia - Fundamental researches, 9, 112-113 [in Russian].

17 Dobrovolskii, G.V., \& Babeva, I.P. (2003). Strukturno-funktsionalnaia rol pochv i pochvennoi bioty v biosphere [Structural and functional role of soils and soil biota in the biosphere]. Moscow: Nauka [in Russian].

18 Alekseev, Yu.V. (1987). Tiazhelye metally $v$ pochvakh i rasteniiakh [Heavy metals in soils and plants]. Leningrad: Ahropromizdat [in Russian].

19 Esenzholova, A.Zh., \& Panin, M.S. (2013). Bioindikatsionnaia sposobnost listev drevesnykh i kustarnikovykh nasazhdenii dlia otsenki zahriazneniia sredy tiazhelymi metallami v zone deistviia metallurhicheskoho kompleksa [Bioindicative ability of leaves of tree and shrub stands for assessment of heavy metal pollution in the area of operation of the metallurgical complex]. Ekolohiia $i$ promyshlennost Rossii - Ecology and industry in Russia, 7, 49-53 [in Russian].

20 Sibirkina, A.R. (2014). Bioheokhimicheskie osobennosti nakopleniia soedinenii tiazhelykh metallov razlichnymi soobshchestvami sosnovykh borov Semipalatinskoho Priirtyshia [The content of heavy metals in the Sands of the pine forest of the Semipalatinsk Irtysh region of the Kazakhstan Republic]. Sovremennye problemy nauki i obrazovaniia - Modern problems of science and education, 3. URL: http://www.scienceeducation.ru/117-13005 [in Russian]

21 Korolyov, A.N., \& Boev, V.A. (2017). Tiazhelye metally v pochvakh i ovoshchnykh kulturakh v zone vliianiia tsementnoho zavoda horoda Semei [Heavy metals in soils and vegetable crops in the zone of influence of Semey cement plant]. Vestnik Omskoho hosudarstvennoho ahrarnoho universiteta - Bulletin of Omsk State Agrarian University, 1, $27-33$ [in Russian]. 